\title{
STRATEGI JIGSAW DALAM MENINGKATKAN MINAT BELAJAR MAHASISWA PADA SEMESTER GANJIL PROGRAM STUDI MANAJEMEN STIE KRIDATAMA BANDUNG TAHUN 2017-2018
}

\author{
${ }^{1}$ Dewi Endah Fajariana \\ ${ }^{1}$ Sekolah Tinggi Ilmu Ekonomi (STIE) Kridatama Bandung \\ Email: dewiendah.stiekridatama@gmail.com
}

\begin{abstract}
Environmental changed requires organizations to adapt. Organizations must integrated both internally and innovatively. The quality of education in educational institutions affects the quality of education nationally. Where the quality, determined by the students, lecturers, curriculum, learning strategies, media, infrastructure, time, availability of funds, community and socio-culture. Thus, every educational institution was no exception Institute of Economic Science Kridatama Bandung needed a new learning strategy. STIE Kridatama Bandung Campus Majority of student employees were required to receive higher education by companies and institutions where they work, then there must be problems as follows: a) Lazy learning, b) No concentration when lecturers explained, c) Passive students when lecturers explained, d) Own discussion with other friends, e) Gain low grades, therefore special handling needed to address such issues with innovative learning strategies such as jigsaw. The research method used was qualitative approach through observation on 84 students with the provision of UTS and UAS tests for their interest in learning. From the results of research implementation, the learning done by lecturers through jigsaw strategy, student activity showed there was improvement. Thus, the lecturer's learning process and learning strategy of one unity can not be separated. In conclusion, that lecturers and learning strategies were needed in supporting the learning process in universities to achieve quality education.
\end{abstract}

Keywords: Strategy, Jigsaw, Increase, Interests, Learning.

\begin{abstract}
ABSTRAK
Perubahan lingkungan menuntut organisasi menyesuaikan diri. Organisasi harus melakukan integrasi internal sekaligus inovatif. Kualitas pendidikan pada lembaga pendidikan mempengaruhi mutu pendidikan secara nasional. Dimana kualitas tersebut, ditentukan oleh peserta didik, dosen, kurikulum, strategi pembelajaran, media, sarana prasarana, waktu, ketersediaan dana, masyarakat dan sosial budaya. Jadi, setiap lembaga pendidikan tidak terkecuali Sekolah Tinggi ILmu Ekonomi Kridatama Bandung perlu strategi pembelajaran yang baru. Kampus STIE Kridatama Bandung mayoritas mahasiswa karyawan yang dituntut mengenyam pendidikan tinggi oleh perusahaan dan instansi tempat mereka bekerja, sehingga pasti ada masalah-masalah sebagai berikut: a) Malas belajar, b) Tidak konsentrasi saat dosen menerangkan, c) Mahasiswa pasif saat dosen menerangkan, d) Diskusi sendiri dengan teman sebelahnya, e) Mendapatkan nilai yang rendah sehingga diperlukan penanganan khusus mengatasi masalah-masalah tersebut dengan strategi pembelajaran yang inovatif seperti jigsaw. Metode penelitian yang digunakan yaitu pendekatan kualitatif melalui observasi pada mahasiswa yang berjumlah 84 mahasiswa dengan pemberian test UTS dan UAS untuk minat mereka dalam belajar. Dari hasil pelaksanaan penelitian, pembelajaran yang dilakukan oleh dosen melalui strategi jigsaw, aktivitas mahasiswa menunjukan ada peningkatan. Jadi, proses pembelajaran dosen dan strategi pembelajaran satu kesatuan yang tidak dapat dipisahkan. Sehingga dosen dan strategi pembelajaran sangat diperlukan dalam menunjang proses pembelajaran di perguruan tinggi untuk mencapai pendidikan berkualitas.
\end{abstract}

Kata kunci: Strategi, Jigsaw, Meningkatkan, Minat, Belajar. 


\section{PENDAHULUAN}

Perubahan lingkungan menuntut organisasi untuk menyesuaikan diri. Untuk itu, sebuah organisasi harus lebih progresif, mampu melakukan integrasi internal sekaligus inovatif. Penopang keunggulan bersaing sebuah organisasi adalah keunggulannya dalam belajar sebagai proses yang mendasari dan melahirkan perubahan.

Pendidikan pada setiap jenjang sebagai suatu subsistem pendidikan nasional merupakan faktor kunci dan memiliki peran yang sangat strategis dalam mencapai tujuan pendidikan nasional. Karena, pada hakikatnya penyelenggaraan dan keberhasilan proses pendidikan sangat tergantung dari mutu setiap jenjang pendidikan secara parsial. Oleh sebab itu tidaklah berlebihan adanya tuntutan terhadap accountability (pertanggungjawaban) dari lembaga pendidikan untuk menjawab permasalahan aktual yang memang sudah lama dirasakan semua pihak yang terkait dengan masalah kualitas pendidikan.

Kualitas pendidikan pada setiap lembaga pendidikan akan berpengaruh terhadap mutu pendidikan secara nasional. Derajat kualitas pendidikan ditentukan oleh komponenkomponen peserta didik, guru/ pendidik, kurikulum, strategi pembelajaran, media, sarana dan prasarana, waktu dan ketersediaan dana, serta masyarakat dan sosial budaya. Pada dasarnya, tingkat kualitas semua komponen memberikan kontribusi dan warna terhadap proses pendidikan secara keseluruhan. Untuk itu dalam upaya mencapai sistem pendidikan yang akuntanbel, maka seharusnya setiap pendidik mampu menciptakan suatu strategi pembelajaran yang baru.

Dick and Carey (1985) menyebutkan bahwa strategi pembelajaran itu adalah suatu set materi dan prosedur pembelajaran yang digunakan secara bersama-sama untuk menimbulkan hasil belajar pada siswa. Jenis-jenis strategi pembelajaran (1) Strategi Pembelajaran Ekspositori, (2) Strategi Pembelajaran Inkuiri, (3) Strategi Pembelajaran Kooperatif. Strategi pembelajaran kooperatif adalah model pembelajaran dengan menggunakan sistem pengelompokkan/ tim kecil, yaitu antara empat sampai enam orang yang mempunyai latar belakang kemampuan akademis, jenis kelamin, ras atau suku yang berbeda. Salah satu strategi pembelajaran kooperatif adalah JIGSAW. Model pembelajaran Jigsaw adalah model pembelajaran kooperatif yang dikembangkan dan diuji coba oleh Elliot Aroson dkk dari Universitas Texas dan diadopsi oleh Slavin dkk di Universitas John Hopkins (Trianto, 2007:56).

Untuk itulah setiap lembaga pendidikan tidak terkecuali Sekolah Tinggi ILmu Ekonomi Kridatama Bandung perlu strategi pembelajaran yang baru, yang bertujuan untuk membekali mahasiswa belajar untuk mampu hidup beradaptasi dan berdampingan dengan Lembaga Pendidikan yang lain. Pendidikan akan menjadi instrument penting dalam pembentukan jati diri mahasiswa yang nantinya akan terasa pada saat mereka menyelesaikan studinya dan terjun langsung di tengah-tengah masyarakat. Sesuai dengan visi STIE adalah menjadi Sekolah Tinggi IImu Ekonomi Kridatama Bandung yang mengkonsentrasikan diri pada pembentukan lulusan yang kompeten di bidang Akuntansi dan Manajemen yang siap bekerja serta menyesuaikan diri terhadap perkembangan ilmu pengetahuan secara global sedangkan misi dari Sekolah Tinggi ILmu Ekonomi Kridatama Bandung 1) meningkatkan kualitas dan perluasan cakupan pendidikan tinggi untuk menghasilkan sumber daya manusia dengan pengetahuan keahlian, kemampuan manajemen dan akuntansi yang semakin kompetitif. 2) mengembangkan sumberdaya manusia berdasarkan nilai-nilai kebudayaan yang religius dan memenuhi tuntutan zaman serta memberi arah perubahan dalam rangka membangun masyarakat Indonesia sebagai masyarakat utama. Maka dari itu, belajar merupakan hal yang paling penting untuk seorang mahasiswa. Sedangkan dalam kampus STIE Kridatama Bandung basic mahasiswa mayoritas karyawan yang dituntut untuk mengenyam pendidikan tinggi oleh perusahaan atau instansi tempat mereka bekerja, jadi tidaklah mungkin masalah-masalah sebagai berikut pasti terjadi di perguruan tinggi khususnya kelas karyawan :

a. Malas untuk belajar, 
b. Tidak konsentrasi pada saat dosen menerangkan

c. Mahasiswa pasif pada saat dosen menerangkan

d. Berdiskusi sendiri dengan teman sebelahnya yang bukan tentang mata kuliah yang sedang diikutinya dan

e. Akhirnya mereka mendapatkan nilai yang rendah.

Sehingga diperlukan penanganan khusus untuk mengatasi masalah-masalah tersebut dengan strategi mengajar yang inovatif seperti strategi mengajar jigsaw bukan dengan strategi ceramah yang cenderung membuat mereka tambah mengantuk dan tidak fokus menerima mata kuliah.

Berikut adalah data nilai UTS mahasiswa program studi manajemen kelas manajemen operasional dan metode penelitian:

Tabel 1

Data nilai UTS Ganjil 2017-2018

\begin{tabular}{|l|c|c|c|c|}
\hline $\begin{array}{c}\text { Mat } \\
\text { kul }\end{array}$ & Klasifikasi & Frekuensi & Nilai & $\begin{array}{c}\text { Persen } \\
\text { tase }\end{array}$ \\
\hline MO & III-A & 32 & 70 & 22.4 \\
\hline MO & III-B & 14 & 60 & 8.4 \\
\hline Metlit & VII-A & 21 & 70 & 14.7 \\
\hline Metlit & VII-B & 17 & 70 & 11.9 \\
\hline
\end{tabular}

Sumber:Biro Akademik STIE Kridatama Bandung Ganjil 2017-2018.

Sesuai dengan pendapat ahli yang menyatakan bahwa faktor-faktor yang mempengaruhi minat belajar yaitu faktor intern dan faktor ekstern yang ada di diri individu yang sedang belajar. Faktor ekstern yaitu sekolah atau perguruan tinggi harus memiliki metode mengajar atau strategi mengajar yang dapat membangkitkan rasa ingin belajar yang tinggi pada mahasiswa sehingga mereka dapat memperoleh nilai yang tinggi dan ilmu yang dapat diserap serta diamalkan kelak di dunia kerja setelah lulus kuliah. Faktor sekolah berupa metode mengajar merupakan suatu cara atau jalan yang harus dilalui di dalam mengajar agar orang lain menerima, menguasai dan mengembangkannya (Slameto, 2010:65).

Objek penelitian dari jurnal ini adalah mahasiswa manajemen yang mengontrak mata kuliah manajemen operasional dan metode penelitian Sekolah Tinggi ILmu Ekonomi Kridatama Bandung yang berjumlah 84 mahasiswa. Adapun tujuan dari jurnal ini adalah meningkatkan minat belajar mahasiswa dengan strategi jigsaw pada program studi manajemen ganjil tahun akademik 2017-2018. Hasil dari penelitian ini akan diharapkan dapat berguna bagi pihak-pihak sebagai berikut: 1) Sekolah Tinggi ILmu Ekonomi (STIE) Kridatama Bandung sebagai bahan pustaka yang dapat dibaca oleh dosen dan mahasiswa untuk bahan pertimbangan dalam menyusun karya ilmiah selanjutnya dan sebagai bahan masukan bagi dosen dalam membuat strategi pembelajaran dalam mengajar di kelas karyawan, 2) Peneliti sebagai bekal dan sarana pengembangan ilmu pengetahuan yang diperoleh selama mengajar di Sekolah Tinggi Ilmu Ekonomi (STIE) Kridatama Bandung.

\section{LANDASAN TEORI}

\section{Strategi}

Dalam Kamus Besar Bahasa Indonesia, "strategi adalah rencana yang cermat mengenai kegiatan untuk mencapai sasaran khusus" (Tim Pusat Pembinaan dan Pengembangan Bahasa, 2005:744).

Dick and Carey (1985) menyebutkan bahwa strategi pembelajaran itu adalah suatu set materi dan prosedur pembelajaran yang digunakan secara bersama-sama untuk menimbulkan hasil belajar pada siswa. Jenis-jenis strategi pembelajaran (1) Strategi Pembelajaran Ekspositori, (2) Strategi Pembelajaran Inkuiri, (3) Strategi Pembelajaran 
Kooperatif. Strategi pembelajaran kooperatif adalah model pembelajaran dengan menggunakan sistem pengelompokkan/ tim kecil, yaitu antara empat sampai enam orang yang mempunyai latar belakang kemampuan akademis, jenis kelamin, ras atau suku yang berbeda. Salah satu strategi pembelajaran kooperatif adalah JIGSAW.

\section{Jigsaw}

Model strategi pembelajaran Jigsaw adalah model pembelajaran kooperatif yang dikembangkan dan diuji coba oleh Elliot Aroson dkk dari Universitas Texas dan diadopsi oleh Slavin dkk di Universitas John Hopkins (Trianto, 2007:56).

1. Mahasiswa di kelompokkan ke dalam = 4 mahasiswa

2. Tiap orang dalam tim diberi bagian materi yang berbeda

3. Tiap orang dalam TIM diberi bagian materi yang ditugaskan

4. Anggota dari tim yang berbeda yang telah mempelajari bagian /sub bab yang sama bertemu dalam kelompok baru (kelompok ahli) untuk mendiskusikan sub bab mereka

5. Setelah Selesai diskusi sebagai tim ahli tiap anggota kembali ke kelompok asal dan bergantian mengajar teman satu tim mereka tentang sub bab yang mereka kuasai dan tiap anggota lainnya mendengarkan dengan sungguh sungguh

6. Tiap tim ahli mempresentasikan hasil diskusi

7. Dosen memberi evaluasi

8. Penutup

\section{Meningkatkan}

Dalam Kamus Besar Bahasa Indonesia, "meningkatkan adalah menaikkan derajat, taraf serta mempertinggi dan memperhebat suatu usaha atau kegiatan" (Tim Pusat Pembinaan dan Pengembangan Bahasa, 2005:744).

Berdasarkan pengertian tersebut meningkatkan tersirat adanya unsur proses yang bertahap dari tahap terendah, tahap menengah dan tahap akhir atau tahap puncak. Sedangkan meningkatkan yang peneliti maksudkan adalan meningkatkan minat belajar mahasiswa yang awalnya mendapat nilai rendah ditingkatkan agar hasil belajarnya lebih tinggi atau memuaskan dengan cara merubah strategi belajarnya.

\section{Minat}

Dalam Kamus Besar Bahasa Indonesia, "minat adalah kecenderungan hati yang tinggi terhadap sesuatu atau gairah atau keinginan" (Tim Pusat Pembinaan dan Pengembangan Bahasa, 2005:744).

Masalah yang dihadapi dalam mata kuliah manajemen operasional dan metode penelitian di STIE Kridatama Bandung adalah kurangnya minat belajar mahasiswa terhadap mata kuliah tersebut. Hal ini menyebabkan kegagalan dalam belajar seperti pendapat S. Nasution (2000:73) yaitu: "Pelajaran dapat berjalan dengan lancar, apabila ada minat. Mahasiswa malas belajar dan gagal karena tidak adanya minat". Dari pendapat tersebut di atas, peneliti berkesimpulan ternyata kegagalan siswa di dalam belajar kurangnya minat dari mahasiswa terhadap mata kuliah. Mahasiswa sebagai subjek agar memiliki potensi di dalam dirinya meliputi.

1) Karakteristik dari pribadinya

2) Minat dan kepentingan pribadinya

3) Tingkat perkembangan fisik dan mentalnya

4) Pengetahuan yang dimilikinya

5) Permasalahan yang dihadapinya

6) Latar belakang sosial budaya, ekonomi dan lingkungannya.

Minat yang ada dalam diri mahasiswa, menurut pendapat Moh Surya (1998:241) adalah sebagai berikut:

1) Minat Volinter

Adalah minat yang timbul secara sukarela dari pihak mahasiswa tanpa ada pengaruh yang sengaja ditimbulkan dari luar. 
2) Minat Involinter

Adalah minat yang timbul dari dalam diri mahasiswa dengan pengaruh suatu situasi yang diciptakan oleh pengajar.

3) Minat Non Volinter

Adalah minat yang ditimbulkan secara disengaja.

Sedangkan menurut Rooijakkers (1996:25) dalam bukunya Mengajar dengan Sukses, mengemukakan sebagai berikut: "Minat adalah suatu sifat yang relatif menetap pada diri seseorang". Minat ini besar sekali pengaruhnya terhadap belajar sebab dengan minat seseorang tidak mungkin melakukan sesuatu. Minat mahasiswa merupakan faktor utama yang menentukan derajat keaktifan belajar mahasiswa.

Minat adalah kecenderungan jiwa yang tetap untuk memperhatikan dan mengenang beberapa aktivitas atau kegiatan (Slameto, 2010:15).

Minat merupakan suatu kegiatan yang dilakukan oleh siswa secara tetap dalam melakukan proses belajar. Sesuai dengan pendapat Slameto (2010: 57) minat adalah kecenderungan yang tetap untuk memperhatikan dan mengenang beberapa kegiatan. Kegiatan yang diminati siswa, diperhatikan terus-menerus yang disertai rasa senang dan diperoleh rasa kepuasan. Lebih lanjut dijelaskan minat adalah suatu rasa suka dan ketertarikan pada suatu hal atau aktivitas, tanpa ada yang menyuruh. Seseorang yang memiliki minat terhadap kegiatan tertentu cenderung memberikan perhatian yang besar terhadap kegiatan tersebut. Tentunya dalam melaksanakan kegiatan dan usaha pencapaian tujuan perlu adanya pendorong untuk menumbuhkan minat yang dilakukan oleh dosen, semangat pendidik dalam mengajar mahasiswa berhubungan erat dengan minat mahasiswa yang belajar. Apabila dosen mempunyai semangat untuk memperhatikan dan mengenang kegiatan mengajar akan sangat mempengaruhi minat mahasiswa terhadap materi yang diajarkan. Seorang dosen tidak dapat membangkitkan minat siswa, jika dosen tersebut tidak memiliki minat dalam memberikan materi mata kuliah.

\section{Belajar}

Belajar adalah usaha aktif yang terjadi dalam diri atau mental seseorang untuk mengkonstruksi suatu pengetahuan sehingga menimbulkan perubahan secara kognitif, efektif, dan psikomotor (Suti'ah, 2005:3).

Sedangkan Pengertian belajar menurut Drs. Slameto adalah "Belajar ialah suatu proses usaha yang dilakukan seseorang untuk memperoleh suatu perubahan tingkah laku yang baru secara keseluruhan sebagai hasil pengalamannya sendiri dalam interaksi dengan lingkungannya dan beberapa faktor minat belajar yaitu:

a. Faktor internal: Motivasi, Kebutuhan, Sikap terhadap obyek, Tingkat Kecerdasan dan Kesehatan.

b. Faktor Eksternal: Guru dan Metode mengajar (Slameto, 2010:17).

Menurut Pidarta (2007:206) belajar adalah perubahan perilaku yang relatif permanen sebagai hasil pengalaman dan bisa melaksanakannya pada pengetahuan lain serta mampu mengkomunikasikannya kepada orang lain. Sebagian terbesar dari proses perkembangan berlangsung melalui kegiatan belajar. Belajar yang sederhana atau kompleks, belajar sendiri, atau dengan bantuan guru, belajar dari buku atau dari media elektronika, belajar di sekolah atau dirumah, di lingkungan kerja atau dimasyarakat. Menurut Witherington (Sukmadinata:155) belajar merupakan perubahan dalam kepribadian, yang dimanifestasikan sebagai pola-pola respons yang baru yang berbentuk keterampilan, sikap, kebiasaan , pengetahuan, dan kecakapan.

Menurut Ahmadi (1990: 121 - 123) mengatakan bahwa terdapat beberapa unsur pokok atau ciri-ciri perubahan tingkah laku dalam pengertian belajar: (a) perubahan yang terjadi secara sadar, individu yang belajar menyadari adanya perubahan, (b) perubahan dalam belajar sifat fungsional, (c) perubahan dalam belajar bersifat positif dan aktif, (d) perubahan dalam belajar tidak bersifat sementara, (e) perubahan dalam belajar bertujuan dan terarah, (f) perubahan mencakup seluruh aspek tingkah laku. 


\section{METODOLOGI}

Penelitian ini menggunakan pendekatan kualitatif melalui observasi. Populasi dari penelitian ini berjumlah 84 orang. Sampel dalam penelitian ini adalah kelas mata kuliah manajemen operasional berjumlah 32 mahasiswa manajemen $3 \mathrm{~A}, 14$ manajemen 3B dan mata kuliah metode penelitian berjumlah 21 mahasiswa manajemen 7A, 17 manajemen 7B dengan total keseluruhan sample berjumlah 84 orang. Dalam penelitian ini sampel diambil secara keseluruhan atau sampling jenuh peserta kuliah. Teknik pengumpulan data yaitu pemberian pre-test (saat UTS) dan post-test (saat UAS) untuk mengetahui tingkat keberhasilan mereka belajar. Teknik analisis data menggunakan model Miles and Huberman. Analisis data dalam penelitian kualitatif, dilakukan pada saat pengumpulan data berlangsung, dan setelah selesai pengumpulan data dalam periode tertentu. Pada saat wawancara, peneliti sudah melakukan analisis terhadap jawaban yang diwawancarai. Miles and Huberman mengemukakan bahwa aktivitas dalam analisis data kualitatif dilakukan secara interaktif dan berlangsung secara terus menerus sampai tuntas, sehingga datanya sudah jenuh. Aktivitas dalam analisis data, yaitu data reduction, data display dan conclusion drowing/verification (Sugiyono, 2016:92). Data Reduction berupa permasalahanpermasalahan yang akan dicari solusi dengan penelitian yaitu masalah mahasiswa malas untuk belajar, tidak konsentrasi pada saat dosen menerangkan dan akhirnya mereka mendapatkan nilai yang rendah, data display dibuktikan dengan data tabel yang menunjukkan penurunan nilai dan semangat belajar mahasiswa pada saat di dalam kelas mata kuliah manajemen operasional dan mata kuliah metode penelitian yang menggunakan metode mengajar ceramah, dan conclusion drowing/verification merupakan kesimpulan dalam penelitian ini berisi tentang perbandingan hasil penggunaan strategi mengajar ceramah dengan strategi jigsaw dalam kelas mata kuliah manajemen operasional dan metode penelitian yang menyatakan bahwa penggunaan strategi jigsaw menghasilkan hasil belajar yang diharapkan.

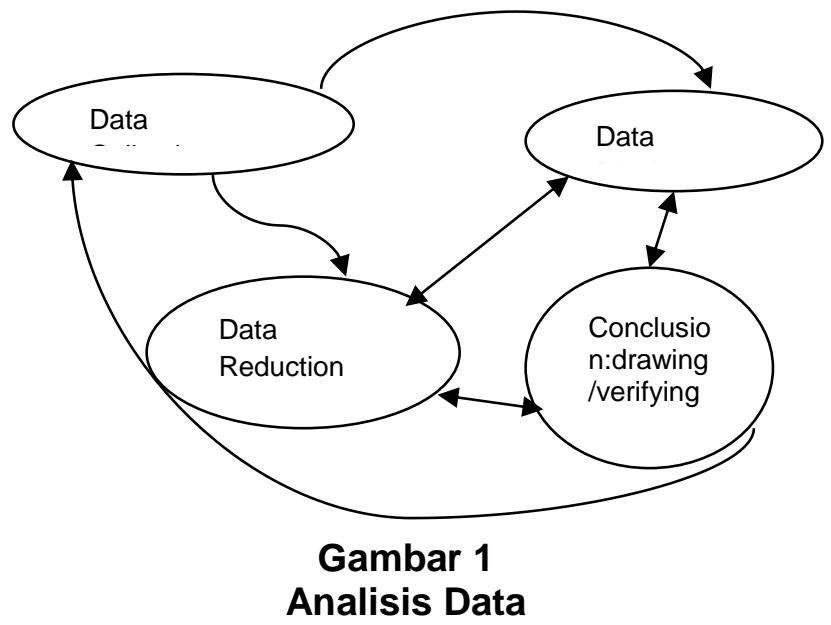

\section{HASIL DAN PEMBAHASAN}

\section{Strategi Jigsaw}

Strategi pembelajaran Jigsaw adalah model pembelajaran kooperatif yang dikembangkan dan diuji coba oleh Elliot Aroson dkk dari Universitas Texas dan diadopsi oleh Slavin dkk di Universitas John Hopkins (Trianto, 2007:56). Dalam strategi jigsaw mahasiswa memiliki banyak kesempatan untuk mengemukakan pendapatnya, artinya di sini mahasiswa dituntut untuk aktif belajar dan mengolah informasi yang diperolehnya sehingga tidak ada lagi mahasiswa yang pasif dalam menyelesaikan materi yang diberikan oleh dosen. Berikut ini, Langkah- Langkah dalam strategi jigsaw:

1. Mahasiswa di kelompokkan ke dalam $=4$ mahasiswa 
2. Tiap orang dalam tim diberi bagian materi yang berbeda

3. Tiap orang dalam TIM diberi bagian materi yang ditugaskan

4. Anggota dari tim yang berbeda yang telah mempelajari bagian /sub bab yang sama bertemu dalam kelompok baru (kelompok ahli) untuk mendiskusikan sub bab mereka

5. Setelah Selesai diskusi sebagai tim ahli tiap anggota kembali ke kelompok asal dan bergantian mengajar teman satu tim mereka tentang sub bab yang mereka kuasai dan tiap anggota lainnya mendengarkan dengan sungguh sungguh

6. Tiap tim ahli mempresentasikan hasil diskusi

7. Dosen memberi evaluasi

8. Penutup

Pada tahap awal mahasiswa dikelompokkan dalam beberapa kelompok dan masing-masing indivivu dalam kelompok diberi kasus yang berbeda, langkah berikutnya setiap anggota kelompok bergabung dengan anggota kelompok lain dan membahas kasus yang sama, kelompok ini disebut kelompok tim ahli. Kelompok tim ahli inilah yang nantinya akan kembali ke kelompok asal dan memberi penjelasan tentang hasil pembahasan di kelompok tim ahli. Pada akhirnya masing-masing kelompok akan mempresentasikan hasil diskusi mereka. Strategi jigsaw memiliki keunggulan sebagai berikut:

a. Mahasiswa tidak sepenuhnya tergantung pada dosen

b. Mahasiswa berpeluang mengungkapkan pendapatnya secara verbal dan menguji serta membandingkannya dengan pendapat orang lain dalam kelompoknya dan pendapat dari kelompok lain.

c. Mahasiswa terlatih untuk tanggap kepada orang lain dengan menyadari keterbatasan dirinya serta menerima segala perbedaan.

d. Mahasiswa terbiasa untuk bertanggung jawab atas tugas yang diberikan kepadanya.

e. Mahasiswa dapat meningkatkan kemampuan menggunakan informasi dan yang membuat abstrak menjadi nyata.

f. Mahasiswa akan termotivasi lewat aktivitas berinteraksi dengan orang lain sehingga menumbuhkan inovasi serta terangsang untuk berfikir dan memecahkan masalah tanpa takut membuat kesalahan.

g. Mahasiswa dapat menguji ide dan pemahaman sendiri serta mampu menerjemahkan umpan balik dengan cekatan.

Selain keunggulan yang dimiliki, juga ada kelemahannya yaitu :

a. Metode ini sering hanya melibatkan mahasiswa yang mampu dan pandai.

b. Adanya perselisihan pendapat dan terjadi perpecahan dalam kelompok karena mempertahankan pendapat dalam menyelesaikan masalah.

c. Keberhasilan strategi belajar ini tergantung kepada kemampuan mahasiswa memimpin kelompok atau untuk kerja sendiri.

\section{Meningkatkan Minat Belajar Mahasiswa}

Dalam Kamus Besar Bahasa Indonesia, "meningkatkan adalah menaikkan derajat, taraf serta mempertinggi dan memperhebat suatu usaha atau kegiatan" (Tim Pusat Pembinaan dan Pengembangan Bahasa, 2005:744).

Sedangkan dalam Kamus Besar Bahasa Indonesia, "minat adalah kecenderungan hati yang tinggi terhadap sesuatu atau gairah atau keinginan" (Tim Pusat Pembinaan dan Pengembangan Bahasa, 2005:744). Belajar adalah usaha aktif yang terjadi dalam diri atau mental seseorang untuk mengkonstruksi suatu pengetahuan sehingga menimbulkan perubahan secara kognitif, efektif, dan psikomotor (Suti'ah, 2005:3).

Minat adalah kecenderungan jiwa yang tetap untuk memperhatikan dan mengenang beberapa aktivitas atau kegiatan (Slameto, 2010:15). Sedangkan Pengertian belajar menurut Drs. Slameto adalah "Belajar ialah suatu proses usaha yang dilakukan seseorang untuk memperoleh suatu perubahan tingkah laku yang baru secara keseluruhan sebagai hasil pengalamannya sendiri dalam interaksi dengan lingkungannya dan beberapa faktor minat belajar yaitu: 
a. Faktor internal: Motivasi, Kebutuhan, Sikap terhadap obyek, Tingkat Kecerdasan dan Kesehatan.

b. Faktor Eksternal: Guru dan Metode mengajar (Slameto, 2010:17).

Dari hasil pelaksanaan tindakan dilakukan menurut peneliti, bahwa dalam pelaksanaan pembelajaran yang dilakukan oleh dosen melalui strategi pembelajaran kooperatif tipe jigsaw, pada umumnya aktivitas mahasiswa maupun aktivitas dosen menunjukan ada peningkatan pada Ujian Akhir Semester. Peningkatan aktivitas mahasiswa terutama kesiapan mahasiswa mengikuti kegiatan kerjasama diskusi antar mahasiswa dalam satu kelompok pada saat mengerjakan soal serta diskusi antar mahasiswa dan dosen pada saat memaparkan dan mempersentasikan hasil kerja kelompok. Peningkatan aktivitas dosen terutama pada kemampuan dosen untuk mengelola waktu dan memberikan bimbingan kepada mahasiswa menjadi baik.

Bukti dari hasil tindakan strategi jigsaw dapat dilihat dari grafik di bawah ini:

Tabel 2

Data nilai UAS Ganjil 2017-2018

\begin{tabular}{|l|c|c|c|c|}
\hline $\begin{array}{c}\text { Mat } \\
\text { kul }\end{array}$ & Klasifikasi & $\begin{array}{c}\text { Fre } \\
\text { kuensi }\end{array}$ & Nilai & $\begin{array}{c}\text { Persen } \\
\text { tase }\end{array}$ \\
\hline MO & III-A & 32 & 90 & 28.8 \\
\hline MO & III-B & 14 & 80 & 11.2 \\
\hline Metlit & VII-A & 21 & 90 & 18.9 \\
\hline Metlit & VII-B & 17 & 90 & 15.3 \\
\hline
\end{tabular}

Sumber:Biro Akademik STIE Kridatama Bandung Ganjil 2017-2018.

Tabel di atas menunjukkan bahwa dengan adanya tindakan menggunakan strategi jigsaw, minat mahasiswa menjadi meningkat untuk belajar. Pada setiap manusia, minat memegang peranan penting dalam kehidupan dan mempunyai dampak yang besar atas perilaku dan sikap, minat menjadi sumber motivasi yang kuat untuk belajar, mahasiswa yang berminat terhadap suatu kegiatan baik itu bekerja maupun belajar, akan berusaha sekuat tenaga untuk mencapai tujuan yang diinginkan.

Fungsi minat dalam belajar lebih besar sebagai motivating force yaitu sebagai kekuatan yang mendorong mahasiswa untuk belajar. mahasiswa yang berminat kepada mata kuliah akan tampak terdorong terus untuk tekun belajar, berbeda dengan mahasiswa yang sikapnya hanya menerima mata kuliah saja.

\section{PENUTUP}

Kesimpulan dari penelitian ini bahwa terdapat hubungan yang signifikan antara meningkatkan minat belajar mahasiswa dengan strategi jigsaw pada program studi manajemen ganjil tahun akademik 2017-2018.

Dalam proses pembelajaran dosen dan strategi pembelajaran atau metode mengajar merupakan satu kesatuan yang tidak dapat dipisahkan. Sehingga dosen dan metode mengajar sangat mutlak diperlukan dalam menunjang proses pembelajaran di perguruan tinggi untuk mencapai pendidikan yang berkualitas.

\section{DAFTAR PUSTAKA}

Buku

Ahmadi, 1990. Psikologi Belajar. Jakarta: Rineka Cipta.

Kamus Bahasa Indonesia. 2005. Tim Pusat Pembinaan dan Pengembangan Bahasa.

Moh. Surya, 1998. "Psikologi Kependidikan”. Penerbit IKIP Bandung.

Peraturan Akademik Sekolah Tinggi Ilmu Ekonomi Kridatama. 2016. Bandung.

Pidarta, Made. 2007. Landasan Kependidikan. Jakarta: Rineka Cipta. 
Rooijakkers, 1996, "Mengajar Dengan Sukses”, Jakarta, penerbit PT. Grasindo.

Sukmadinata, Nana Syadih. 2007. Landasan Psikologi Proses Pendidikan. Bandung: PT Remaja Rosdakarya.

Suti'ah. 2005. Manajemen pendidikan, Jakarta: Rineka Cipta.

Slameto. 2010. Belajar dan Faktor-Faktor yang Mempengaruhi. Jakarta: Rineka Cipta.

Sugiyono. 2016. Metode Penelitian Kualitatif. Bandung: CV. Alfabeta.

S.Nasution, 2000, “Pengajaran Akuntansi”. Jakarta, Penerbit Yudistira.

Trianto. 2007. Mendesain Model Pembelajaran Inovatif-Progresif. Surabaya. Kencana Prenada Media Group.

Undang-Undang Nomor 16 tahun 2007 tentang Standar Kualifikasi Akademik dan Kompetensi Guru. Standar Nasional Pendidikan.

\section{Artikel in Press :}

Jurnal

Hanafi Pontoh, Jamaludin, dan Hasdin. 2005. Penerapan Model Pembelajaran Jigsaw Untuk Meningkatkan Hasil Belajar IImu Pengetahuan Sosial (IPS) Siswa Kelas V SD Inpres Salabenda Kecamatan Bunta. Jurnal Kreatif Tadulako Online Vol. 4 No. 11 ISSN 2354-614X.

Mulyani, ljah. 2003. Model Pembelajaran Jigsaw dalam Upaya Meningkatkan Hasil Belajar Akuntansi. Prosiding Seminar Nasional Pendidikan Akuntansi dan Keuangan. Pengembangan Pendidikan Akuntansi dan Keuangan yang Berkelanjutan". 